\section{Estimation of the eeconomic values for the important traits of zel sheep in the intensive production system using a bio-economic model}

\author{
Kian Pahlevan Afshar, \\ Mehran Aboozari
}

Department of Animal Sciences, Islamic Azad University, Abhar Branch, Abhar, Iran

\begin{abstract}
To estimate economic values (EVs) of seven important traits including pregnancy rate (PR), litter size (LS), lamb weight at birth (BW0), three (weaning; BW3), six (BW6) and nine (BW9) months weight and survival rate until the age of 6 months (SR) in Zel sheep under an intensive production system in Mazandaran province of Iran, data from two farms were analysed using a bio-economic model. Variable costs accounted for about $99 \%$ of the total costs and the feed costs had the highest proportion with 72.54\%. Among the income sources, the sale of surplus animals formed $81.4 \%$ of the total revenues. The EVs were estimated as the amount of change in the profit of the system after each trait mean increased by both $1 \%$ and one unit, while all other traits were constant at their mean values. The most important trait in this system was LS, followed by SR, PR, BW9, BW3, BW6 and BW0 respectively. The sensitivity of EVs was investigated by changing prices of feed and live weight of 9-month-old lambs by $\pm 20 \%$. Results showed that the EV of BW9 was the most constant and EV of BW0 was the most variable. As the prices of feed and live weight of 9-month-old lambs were simultaneously changed by $\pm 20 \%$, the variation in the EVs decreased and they showed more consistency. This study showed that the profitability in an intensive production system of Zel sheep could be increased by improving LS, SR, PR and BW9.
\end{abstract}

\section{Introduction}

According to the Food \& Agricultural Organization of the United Nations, Iran has $53,800,000$ sheep that are reared under two major production systems: rural and migratory (nomadic) systems. ${ }^{1}$ Income from different forms of animal production is about $41 \%$ of all agricultural income in Iran and therefore, has a special place in the national economy. ${ }^{2}$

Nowadays, various methods and systems of sheep production are applied based on economic factors, natural resources and even religious and racial factors. ${ }^{3}$ Therefore, there is no one general model for all different cases in the world. ${ }^{4}$ In modern sheep production, the desire of every farmer is to increase the income, and this is possible only if the improvement of sheep breeding could be a continuous process and a main component of the production technology, and organizational forms of selection must be investigated.5-9 Diversity of breeding goals, different rearing systems, level of farm organization, level of inclusion of government institutions in the development, implementation and maintenance of selection process are some of the factors which influence the development and progress of sheep breeding in a country. ${ }^{10}$

Animal selection is an important part of animal breeding and is usually performed on the basis of a complex of traits. Each of these traits is characterized by its $\mathrm{BV}$ (breeding value) and EV (economic value). The EV of a trait describes the change in the outcome of a defined production system caused by a change in the genetic value of the trait. ${ }^{11}$ Economic values of many important traits for sheep production systems were calculated in the past years. ${ }^{12-19}$ In Iran, EVs of traits have been calculated for various breeds of sheep kept in rural and migratory systems. ${ }^{17,20}$ but there is no study that calculated EVs of traits for intensive sheep production system. The objective of this study was to estimate EVs for important traits of Zel sheep breed under intensive production system using a bio-economic approach.

\section{Materials and Methods}

\section{Collection of information and defini- tions}

In order to estimate productive, reproductive, management and economical parameters for use in bio-economical equations and to calculate the EVs of traits, two farms with the flock sizes of 3400 and 900 head of Zel sheep in Mazandaran province of Iran, were studied from the beginning of September 2015 to September 2017. The production system of the farms was completely intensive and in all over the year, animals have been kept and fed inside pens. The system of "three lambing in two years" was performed by a pharmacological method of estrus synchronization $(\mathrm{CIDR}+\mathrm{eCG})$ at both farms $[\mathrm{CIDR}=$ controlled internal drug release device; $\mathrm{eCG}=$
Correspondence: Kian Pahlevan Afshar, Department of Animal Sciences, Islamic Azad University, Abhar Branch, Abhar, Iran.

E-mail: kianpahlevanafshar1980@gmail.com

Key words: Zel sheep, Economic value, Bioeconomic model, Intensive production system.

Contributions: the authors contributed equally.

Conflict of interest: the authors declare no potential conflict of interest.

Funding: none.

Received for publication: 29 August 2018.

Accepted for publication: 9 January 2019.

This work is licensed under a Creative Commons Attribution NonCommercial 4.0 License (CC BY-NC 4.0).

(C)Copyright K.P. Afshar and M. Aboozari, 2018 Licensee PAGEPress srl, Italy

Veterinary Science Development 2018; 8:7854

equine chorionic gonadotropin]. Animals are fed to meet National Research Council recommendations (2007)21 and feeding costs were calculated. Biological information such as live weights of animal groups, reproduction performance, survival rate and economical information including revenue and cost resources were used in calculation of EVs. The performance data and the management parameters used in the model are summarized in Table 1.

\section{Animal flows and events}

Figure 1 shows a diagram of animal events and flows of an intensive production system for Zel sheep breed. Five animal categories were distinguished according to age: (1) 0 to 3-month-old lambs; (2) 3 to 6month-old lambs; (3) 6 to 12-month-old lambs; (4) breeding rams (>12 months old) and (5) breeding ewes ( $>12$ months old). Age of replacement for females and males was 12 months old and age of selling surplus lambs was 9 months old. The fattening period commenced three months before and continued to sale time of surplus male lambs.

\section{Expenses and revenues resources}

In this study, inputs and outputs of the intensive production system of Zel sheep are:

a) Feeding costs including the concentrate and forages. All five animal categories were fed with a same concentrate, but in different amounts. The rations of animal 
Table 1. Average values of productive, reproductive, management and economic parameters used in the bio-economic model in an intensive production system of Zel sheep.

\begin{tabular}{|c|c|c|c|}
\hline Parameters & $\begin{array}{c}\text { Average ( } \pm \text { SD) } \\
\text { Productive and reproductive variables }\end{array}$ & Min. & Max. \\
\hline Birth weight (kg) & $3.5 \pm 0.19$ & 2.93 & 4.07 \\
\hline Weaning weight $(\mathrm{kg})$ & $20 \pm 2.01$ & 14 & 26 \\
\hline Female lamb weight at 6 months old $(\mathrm{kg})$ & $30 \pm 3.52$ & 28.2 & 40.5 \\
\hline Male lambs weight at 6 months old (kg) & $35 \pm 1.50$ & 30.5 & 39.5 \\
\hline Female lamb weight at 9 months old $(\mathrm{kg})$ & $33 \pm 1.43$ & 28.7 & 37.3 \\
\hline Male lambs weight at 9 months old $(\mathrm{kg})$ & $40 \pm 1.69$ & 35.2 & 45.1 \\
\hline Female lamb weight at 12 months old $(\mathrm{kg})$ & $35 \pm 1.31$ & 31.1 & 38.9 \\
\hline Male lamb weight at 12 months old (kg) & $45 \pm 2.20$ & 38.5 & 51.6 \\
\hline Weight of ewe (kg) & $45 \pm 1.21$ & 41.3 & 48.6 \\
\hline Weight of ram $(\mathrm{kg})$ & $55 \pm 3.32$ & 45.4 & 64.9 \\
\hline Average daily gain from birth to weaning (gr) & $180 \pm 22$ & 147 & 223 \\
\hline Average daily gain from 3 to 6 months old of male lamb (gr) & $170 \pm 13$ & 141 & 214 \\
\hline Average daily gain from 3 to 6 months old of female lamb (gr) & $110 \pm 11$ & 98 & 137 \\
\hline Average daily gain from 6 to 9 months old of male lamb (gr) & $55 \pm 44$ & 8 & 66 \\
\hline Average daily gain from 6 to 9 months old of female lamb (gr) & $33 \pm 32$ & 7 & 42 \\
\hline Annual wool production of ewe $(\mathrm{kg})$ & $1.6 \pm 0.43$ & 0.95 & 2.89 \\
\hline Annual wool production of ram $(\mathrm{kg})$ & $2.5 \pm 0.60$ & 1.2 & 3.8 \\
\hline Annual wool production of lamb (kg) & $0.9 \pm 0.10$ & 0.6 & 1.2 \\
\hline Average age of lambs at the time of weaning (day) & 90 & - & - \\
\hline Pregnancy rate (\%) & 85 & - & - \\
\hline Parturition rate (\%) & 90 & - & - \\
\hline Number of lambing per year per ewe & 1.50 & - & - \\
\hline Litter size & 1.23 & - & - \\
\hline Ratio of rams to ewes & 1 to $40-$ & - & \\
\hline Ewe replacement rate (\%) & 20 & - & - \\
\hline Ram replacement rate (\%) & 21 & - & - \\
\hline Duration of ewe stayed in flock (year) & 6 & - & - \\
\hline Duration of ram stayed in flock (year) & 5 & - & - \\
\hline Ewe culling rate due to disease (\%) & 4 & - & - \\
\hline Mortality rate of replacements (\%) & 1 & - & - \\
\hline Mortality rate of ewes (\%) & 2 & - & - \\
\hline Mortality rate of rams (\%) & 2 & - & - \\
\hline Mortality rate of lambs from birth to weaning (\%) & 4 & - & - \\
\hline Mortality rate of lambs from 3 to 6 months old (\%) & 4 & - & - \\
\hline
\end{tabular}

Days using manual feeding

365

Alfalfa metabolic energy (Mcal/kg of DM)

wheat straw metabolic energy (Mcal/kg of DM)

Corn silage metabolic energy (Mcal/kg of DM)

Concentrate metabolic energy (Mcal/kg of DM)

2.0

Concentrate price (US $\$ / \mathrm{kg}$ of DM)

Alfalfa price (US\$/kg of DM)

Wheat straw (US\$ $/ \mathrm{kg}$ of DM)

Corn silage (US\$/kg of DM)

Cost of ME of ewe ration (US\$/Mcal)

Cost of ME of ram ration (US\$/ Mcal)

Cost of ME of lamb ration till 3 months old (US\$/Mcal)

Cost of ME of lamb ration of 3-6 months old (US\$/Mcal)

Cost of ME of yearling ration (US\$/Mcal)

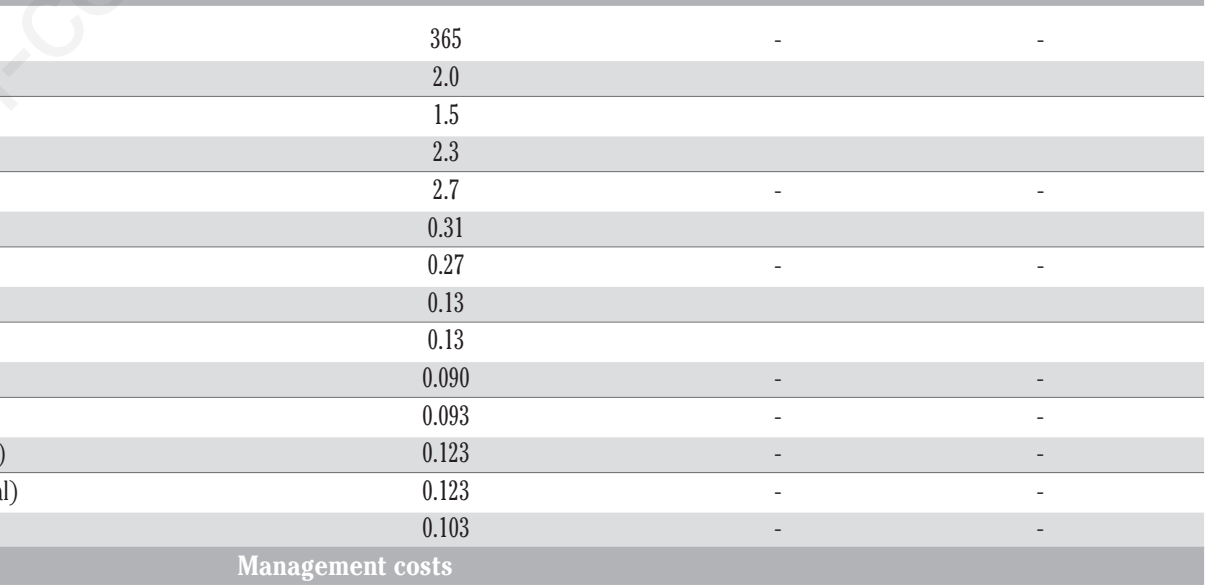

Drug, veterinary service, parasite control and vaccination (US\$/head/year) 10.9

Labor (US\$100 head/month) 196

Shearing (US\$/head/year) $\quad 4.5$

Fuel, water and electricity (US\$/head/year) 19.2

Prices of products

Live lamb (US\$/kg)

$3.37-$

Live culled ewe and ram (US\$ $/ \mathrm{kg}$ )

Wool (US\$ $/ \mathrm{kg})$

2.51

Manure (US\$/kg) 
categories included:

(1) 45 to 3-month-old lambs (weaning lambs): $0.15 \mathrm{~kg}$ of concentrate $+0.15 \mathrm{~kg}$ of alfalfa soft hay in addition to mother milk.

There were slight amounts of concentrate and soft alfalfa hay to stimulate rumen development, but not considered as expenses in calculations.

(2) 3 to 6-month-old lambs: $0.5 \mathrm{~kg}$ of concentrate $+0.5 \mathrm{~kg}$ of alfalfa hay.
(3) 6 to 12 -month-old lambs: $0.7 \mathrm{~kg}$ of concentrate $+0.5 \mathrm{~kg}$ of alfalfa hay $+0.5 \mathrm{~kg}$ of wheat straw $+1.2 \mathrm{~kg}$ of corn silage for the finishing lambs and $0.5 \mathrm{~kg}$ of concentrate $+0.5 \mathrm{~kg}$ of alfalfa hay $+0.5 \mathrm{~kg}$ of wheat straw $+1 \mathrm{~kg}$ of corn silage for the replacing lambs.

(4) Breeding rams ( $>2$ months old): 0.7 $\mathrm{kg}$ of concentrate $+0.5 \mathrm{~kg}$ of wheat straw + $1.5 \mathrm{~kg}$ of corn silage.
(5) Breeding ewes (>12 months old): ): $0.5 \mathrm{~kg}$ of concentrate $+0.3 \mathrm{~kg}$ of wheat straw $+1.3 \mathrm{~kg}$ of corn silage.

The price of each ration (per $\mathrm{kg}$ ) calculated based on amount and price of feedstuffs included in that ration.

Because of different composition of rations in five animal categories and to ease importing the feeding expense to the model, metabolisable energy value of each ration

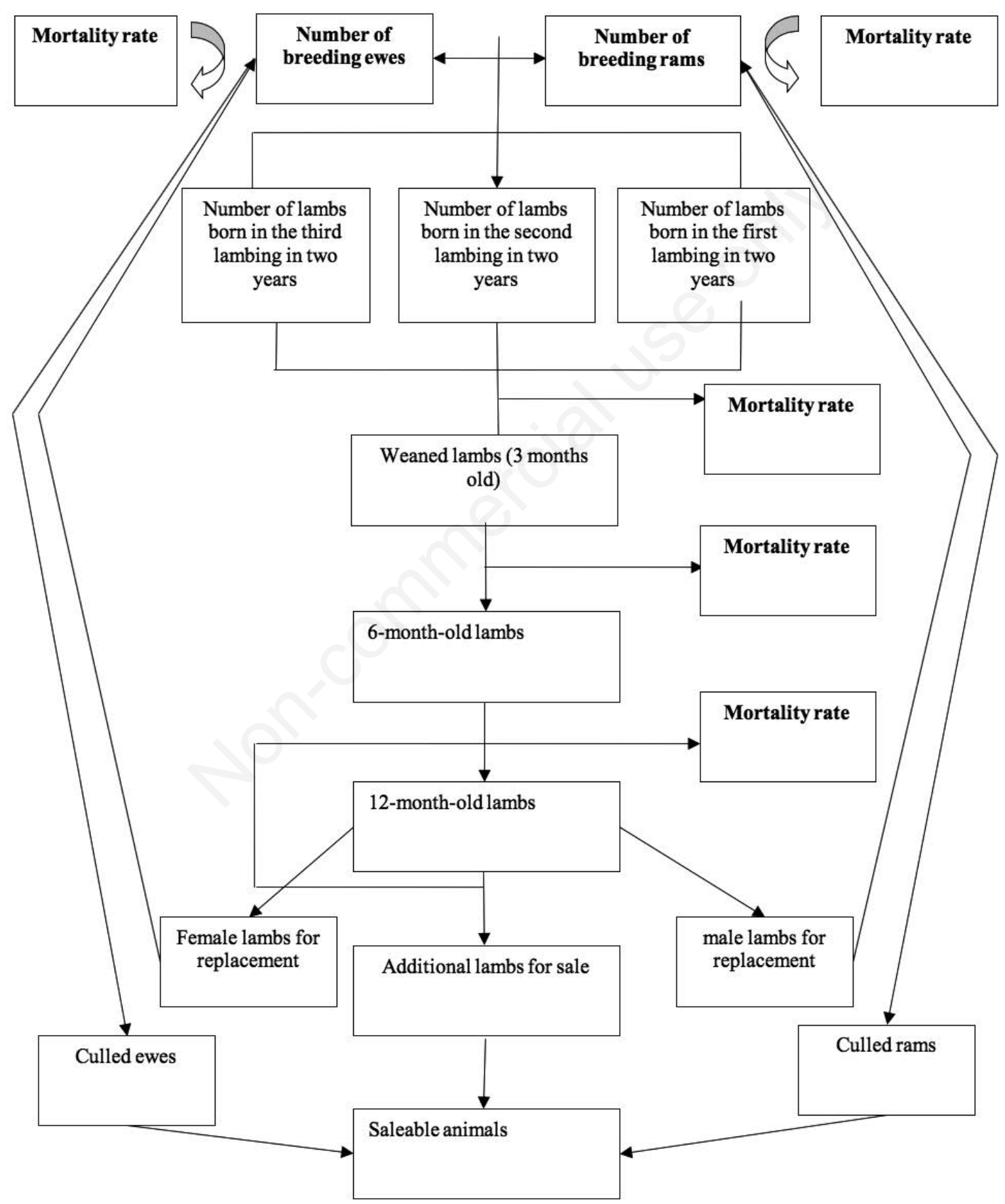

Figure 1. Animal flow in the intensive production system of Zel sheep. 
and its price per Mcal was calculated and used in the model as the feeding expense.

b) Non-feeding costs including labour costs (payments for shepherd, shearing and veterinary services), costs of disease and reproduction control (expenses of hormone therapy for estrus synchronization, drugs, hygiene, vaccinations and other treatments) and other costs (electricity, water, fuel, stall repairs and vehicles).

c) Building costs were considered as a fixed cost.

d) In Zel sheep flocks, income is obtained from the sales of surplus lambs, culled ewes and rams, wool, and manure.

\section{Profit equations}

In the present study, modified Kosgey (2004) equations have been used by following equations:

a) Calculation of the income of different animal groups was described by equation 1:

$$
\begin{aligned}
& R_{e}=\sum_{i=1}^{5}\left[N_{i} \times f_{i} \times\left(1-M R_{i}\right) \times L w_{i} \times P l w_{i}\right]+ \\
& \sum_{i=1}^{5}\left[N_{i} \times f_{i} \times W_{i} \times P w_{i}\right]+\sum_{i=1}^{5}\left[N_{i} \times f_{i} \times M_{i} \times P m\right]
\end{aligned}
$$

where $R_{e}$ is revenue (US \$) per breeding ewe per year, $i$ is one of the five animal groups that described above, $\mathrm{N}_{\mathrm{i}}$ refers to the number of animals in group $i$ divided to the number of breeding ewes, $f_{i}$ is the fraction of sold animals in the group $\mathrm{i}, \mathrm{MR}_{\mathrm{i}}$ is the mortality rate in the group $\mathrm{i}, \mathrm{Lw}_{\mathrm{i}}$ is the live weight $(\mathrm{kg})$ of an animal at the sale time in the group $\mathrm{i}, \mathrm{Plw}_{\mathrm{i}}$ is the price (US\$) of live weight per kilogram at the sale time in the group $\mathrm{i}, \mathrm{W}_{\mathrm{i}}$ is wool production of each animal (kg per year) in the group $\mathrm{i}, \mathrm{Pw}_{\mathrm{i}}$ is the price (US\$) of wool per kilogram in the group $\mathrm{i}, \mathrm{M}_{\mathrm{i}}$ is manure production of each animal (kg per year) in the group i, Pm is the price (US\$) of manure per kilogram (the same price for all groups).

b) The annual feeding costs $\left(\mathrm{C}_{\mathrm{f}}\right)$ were calculated by equation 2 :

$$
C_{f}=\sum_{i=1}^{5}\left[N_{i} \times\left(R f_{i} \times \operatorname{Pr}_{i}\right)\right]
$$

where $R f_{i}$ is the sum of the energy (Mcal) needed for each animal per year in group $i$, $\mathrm{Pr}_{\mathrm{i}}$ is the price of each energy unit (US\$ per Mcal) for the ration of the group $i$.

c) The annual non-feeding costs $\left(\mathrm{C}_{\mathrm{nf}}\right)$ were calculated by equation 3 :

$$
\begin{aligned}
& C_{n f}=\sum_{i=1}^{5}\left[N_{i} \times L_{i}\right]+\sum_{i=1}^{5}\left[N_{i} \times D R C_{i}\right]+ \\
& \sum_{i=1}^{5}\left[N_{i} \times O_{i}\right]
\end{aligned}
$$

where $L_{i}$ is the costs of labour per animal per year in group $\mathrm{i}, \mathrm{DRC}_{\mathrm{i}}$ is costs of disease and reproduction control per animal per year in group $\mathrm{i}, \mathrm{O}_{\mathrm{i}}$ is other costs per animal per year in group $i$.

d) The annual fixed costs $\left(\mathrm{C}_{\mathrm{FCF}}\right)$ were estimated by equation 4 :

$$
C_{F C F}=\sum_{i=1}^{n}\left(P_{i} / D_{i}\right)
$$

where $n$ is the number of fixed cost items, $i$ is one of the fixed cost items, $P_{i}$ is the total payment (US\$) for fixed cost $i, D_{i}$ is durability (years) of fixed cost $i$.

e) Total annual profit (US\$) of the flock $\left(\mathrm{P}_{\text {flock }}\right)$ was described by equation 5 :

$\mathrm{P}_{\text {flock }}=\left[\mathrm{N}_{\text {be }}\left(\mathrm{R}_{\mathrm{e}}-\mathrm{C}_{\mathrm{f}}-\mathrm{C}_{\mathrm{nf}}\right)-\mathrm{C}_{\mathrm{FCF}}\right]$

where $\mathrm{N}_{\text {be }}$ is the number of breeding ewes, $\mathrm{R}_{\mathrm{e}}, \mathrm{C}_{\mathrm{f}}, \mathrm{C}_{\mathrm{nf}}$ and $\mathrm{C}_{\mathrm{FCF}}$ are variable as described above.

\section{Derivation of economic value}

In order to calculate the EV of each trait, the level of the trait was increased by both $1 \%$ of its mean value and 1 unit while all other traits were constant in their mean values and the amount of change in the profit of system was considered as the EV of the trait, as equation 6 :

$V_{I}=P^{\prime}-P(6)$

where $V_{I}$ is the economic value of trait $I, P$ and $P^{\prime}$ are the profits of system before and after increase of the trait by $1 \%$ of its mean value or one unit $(=1 \mathrm{~kg}$ for traits measured in $\mathrm{kg},=1 \%$ for traits measured in percentage, etc).

\section{Sensitivity analysis}

An analysis was performed to investigate the sensitivity of the EVs to changes in levels of cost and revenue factors. The cost and revenue factors used in the sensitivity analysis were feeding cost, price of live weight of 9-month-old lamb and the coincident feeding cost and price of live weight of 9-month-old lamb that were changed by $\pm 20 \%$ of their market values (US\$).

\section{Results}

\section{Revenues and costs}

Table 2 presents the expenses, incomes and profit of the intensive production system for Zel sheep. The values are weighted by the proportion of the animal number in each animal category to total number of breeding ewes, and the totals are expressed per ewe per year. For example, feeding expenses for 0.025 breeding rams was 2.06 US\$ and management costs for 1.62 lambs of 6-12-month-old were 16.31 US\$. Total feeding and management costs per ewe per year were 174.18 and 64.11 US\$, respectively. Feeding and management costs represented $72.54 \%$ and $26.7 \%$ of the total costs, respectively. Annual fixed cost per ewe in this intensive system was 1.8 US\$, about $0.75 \%$ of total costs. Revenue sources were sold live animals (surplus lambs, culled ewes and rams), wool and manure. Selling live animals, manure and wool accounted for about $81.4 \%, 17.5 \%$ and $1.1 \%$ of the total revenues. The total annual profit per breeding ewe was 20.65 US\$.

All the animal categories had negative profits except 6-12-month-old lambs. 0-3 and 3-6-month-old lambs had only manure as a source of revenue and breeding rams and ewes had sale of only culled animals, manure and wool as sources of revenue but the sum of revenues in these two categories was lower than the costs of inputs. Furthermore, the 0-3 and 3-6-month groups had no shares in the income resulted from live sheep and wool. In fact, in this production system, lambs were not sold after milking and were reared for replacement or fattening. For this reason, feeding and management costs of these groups were higher than their income and two groups benefit was negative. The two groups of breeding ewes and breeding rams also had more feeding and management cost than income resulted from selling a part of culled ewes and rams and thereby benefit of this category was also negative. In general, the group of breeding ewes represented the most negative benefit because of large number of animals and higher feeding and managerial costs due to oestrus synchronization and low share in selling culled animals. The group of 6-12-month had positive benefit among all groups due to dominant contribution in selling live animals.

\section{Economic values}

The profit function is generally used to estimate economic value. The profit function is an equation that states net economic income as a function of a series of physical, biological and economical parameters. 
Accordingly, economic value of trait ' $i$ ' is the first derivative of the evaluated profit function in ordinary mean for all traits. A profit equation, which, in general, is linear, is stated as a function of performance a number of traits. But, it should be noted that production systems are complex and often cannot be described by a single benefit function. In bio-economic models, the biological and economical aspects of a given production system are described as a chain of equations.

Table 3 shows the EVs for the considered traits and their sensitivity to changes in cost and revenue factors by $\pm 20 \%$. Economic values for all traits were positive. Economic values for LS, BW3 and SR relatively higher than BW6, BW9, PR and BW0 when the trait value was increased by one unit.

\section{Sensitivity of EVs}

The sensitivity of the trait EVs was investigated by changing feed costs (as the main system input) and price of live weight of 9-month-old lamb (as the main system revenue) and the coincident both of them by $\pm 20 \%$ of their mean market values. With increasing or decreasing feed cost by $\pm 20 \%$, the lowest variations (means the highest stabilities) of EVs were for BW9, SR, LS and $\mathrm{PR}$ (EV variation of $\pm 0.06, \pm 0.08, \pm 0.11$ and \pm 0.11 , means EV stability of $94 \%$, $92 \%, 89 \%$ and $89 \%$, respectively).

\section{Discussion}

In this intensive production system, the total costs for feeding was $72.54 \%$ of the total expenses. The breeding ewe category had the greatest amount of feeding costs with the average of $46.4 \%$ and the breeding ram category had the minimum amount of feeding costs with the average of $1.2 \%$. Ponzoni (1986) 22 pointed out that the cost of feed, although the major cost component for sheep and goat farms is difficult to measure and so is sometimes incorrectly excluded from the definition of selection goals. The difficulty in calculating feed costs occurs mainly with animals reared on pasture. In the present study, all animal categories were fed manually throughout the year; therefore, feeding costs were calculated correctly. The highest amounts of management expenses were for the breeding ewes and 6-12-month-old lambs categories with the average of $52.5 \%$ and $25.4 \%$, respectively, and the lowest was for breeding rams with $1.0 \%$ of the total management costs. The fixed costs in this system were $0.75 \%$ of total expenses and this is due to the high number of animals kept in this intensive production system in comparison to the rural system. Vatankhah $(2005)^{17}$ reported that in the rural production system of Lori Bakhtiari sheep, $2.4 \%$ and $98 \%$ of the total of expenses is dedicated to fix and variable costs, respectively. Haghdoost $(2008)^{20}$ reported variable costs in the rural sheep production system for Arab breed to be $98.5 \%$ while Kosgey (2003) ${ }^{13}$ reported this rate for the tropical regions sheep to be 95\%. Tolone (2011) 16 reported variable costs in the pasture-based system of Valle del Belice breed to be $99 \%$. The observed marginal differences in different investigations can be attributed to the way of entering different assumptions in the model. As an example, in our calculations, transportation cost was not entered into the model as a part of variable costs.

Erkan et al.23 showed that the major part of variable expenses was due to the feed expenses $(62 \%)$ in Toros mountainous villages' sheep farms and Y1ldırım (1993)24 reported that feed costs were $47 \%$ for sheep farms in Çatak Town of Van Province of Turkey. Higher feeding costs in intensive sheep production system in comparison to other systems is due to manual feeding throughout the year. In this study, the revenue resources included sale of live animals, manure and wool. The income from sold live animals was 212.2 US\$ which is $81.4 \%$ of the total income. This finding is different from that reported by Vatankhah (2005) $)^{17}$ reporting income from selling surplus animals made up $95 \%$ of total income. This difference is may be due to the higher production of manure in intensive sheep production in comparison to rural sheep production system. Şahin and Yildirim (2002) 25 found that the lamb value amounted to $68 \%$ of the gross production value in sheep farms of Van Province of Turkey. Kosgey et al.13 indicated that the total amount of meat sold was $89 \%$ of income in

Table 2. Costs, revenues, and profit (US\$) of each animal category per year per breeding ewe for the intensive sheep production system of Zel sheep.

\begin{tabular}{|c|c|c|c|c|c|c|c|}
\hline \multicolumn{2}{|c|}{ 0-3 m.o. lambs } & \multirow{2}{*}{$\begin{array}{c}3-6 \text { m.0. lambs } \\
1.64\end{array}$} & \multirow{2}{*}{$\begin{array}{c}\text { 6-12 m.0. lambs } \\
1.62\end{array}$} & \multicolumn{2}{|c|}{ Breeding rams Breeding ewes } & \multirow{2}{*}{$\begin{array}{c}\text { Total * } \\
-\end{array}$} & \multirow{2}{*}{$\begin{array}{c}\% \text { total } \\
-\end{array}$} \\
\hline $\begin{array}{l}\text { Proportion of animal category } \\
\text { per breeding ewe }\end{array}$ & 1.65 & & & 0.025 & 1 & & \\
\hline \multicolumn{8}{|c|}{ Inputs } \\
\hline Feed & 15.2 & 42.76 & 33.28 & 2.06 & 80.86 & 174.18 & 72.54 \\
\hline $\begin{array}{l}\text { Feed costs of each category } \\
\text { to total feed costs }(\%)\end{array}$ & 8.7 & 24.5 & 19.1 & 1.2 & 46.4 & 100 & - \\
\hline Management & 7.88 & 5.64 & 16.31 & 0.65 & 33.63 & 64.11 & 26.7 \\
\hline $\begin{array}{l}\text { Management costs of each category } \\
\text { to total management costs (\%) }\end{array}$ & 12.3 & 8.8 & 25.4 & 1 & 52.5 & 100 & - \\
\hline Fixed costs & & & & & & 1.8 & 0.75 \\
\hline Total & 23.08 & 48.4 & 49.59 & 2.71 & 114.5 & 240.1 & 100 \\
\hline \multicolumn{8}{|c|}{ Outputs } \\
\hline Sold live animals & 0 & 0 & 185.5 & 0.72 & 26 & 212.2 & 81.4 \\
\hline Manure & 6.7 & 11 & 12.25 & 0.4 & 15.5 & 45.85 & 17.5 \\
\hline Wool & 0 & 0 & 1.16 & 0.03 & 1.5 & 2.7 & 1.1 \\
\hline Total & 6.7 & 11 & 198.9 & 1.15 & 43 & 260.75 & 100 \\
\hline Profit & -16.38 & -37.4 & 149.31 & -1.56 & -71.5 & $20.65^{* *}$ & - \\
\hline
\end{tabular}

*Weighted by animal proportions; **Total profit per breeding ewe (1 US $\$=37000$ Rials). 
tropical sheep breeds. The difference between these studies and ours may be due to milk production as an extra source of revenue in rural system. In current study, selling wool has dedicated $1.1 \%$ of the total income. Khodaei (2004)26 reported that the sale of wool in Gilani sheep in rural sheep production system was $5 \%$ of the total income, which is different from our results.

About the economic values, Lôbo et al. (2011) 15 indicated that increasing values of traits by one unit to calculate their EVs is not a suitable way to compare EVs of traits, because the increase of one unit does not allow a relative comparison, since it does not consider the scale and biological limits of the traits. Therefore, the following discussion concentrates on EVs calculated by increasing values of traits by $1 \%$ of their mean values.

The most important trait in this way was LS, followed by SR, PR, BW9, BW3, BW6 and $\mathrm{BW} 0$, respectively. As the relative economic values of traits were calculated based on the economic value of the BW0, the rel- ative economic value of birth weight was equal to 1 .

Positive EVs for the traits implies that the total revenues resulting from increasing value of a trait by $1 \%$ of its mean value are higher than the total costs. LS was the most important trait. LS, the number of born lambs per lambed ewe, is related to a multiplicative effect that determines the largest source of revenues, that is surplus lambs sold, but also it contributes to the costs. So, litter size (LS) Survival rate before six month (SR) and pregnancy rate (PR) are traits that show good opportunity for improvement in Zel sheep flocks, in spite of their low heritability $(<0.10$; Lôbo et al. 2011). ${ }^{15}$ Improvement of reproductive traits provides a higher profit due to an increase in produced lamb to sale (Tolone et al. 2011). ${ }^{16}$ In this study, EV of PR was low when an increase of one unit of the trait was examined. However, Legarra et al. (2007) 27 and Vatankhah (2005), ${ }^{17}$ reported higher values for this trait. Morais and Madalena (2006) ${ }^{28}$ reported that the traits related to reproduction had high economic values, as found in the present study when their values increased by $1 \%$.

In this study, increasing mortality rate had negative impacts on the system profit, because it resulted in fewer animals for sale. Increasing survival rate (SR) before six months of age increases number of animals available for reproduction and for sale. And if the number of breeding rams and ewes is kept constant, this trait can increase sale of surplus lambs. So, following LS, SR was second important trait affected on the system profit. McManus et al. (2006) 29 estimated that the economic values of number of weaned lambs in intensive system are lower in comparison with semi intensive and extensive sheep production system. But, Morais and Madalena (2006) 28 and Lôbo et al. (2011) ${ }^{15}$ reported that lamb survival rate was an important trait.

Success of the enterprise is concentrated on the price of meat paid at market. This price fluctuates between region of the country and along the year which leads to large

Table 3. Economic values (US\$) of the traits in the base and changed situations and sensitivity of the EVs to changing feed costs (FC) and price of live weight of 9-month-old lamb (L9L) by $\pm 20 \%$ of their mean market values.

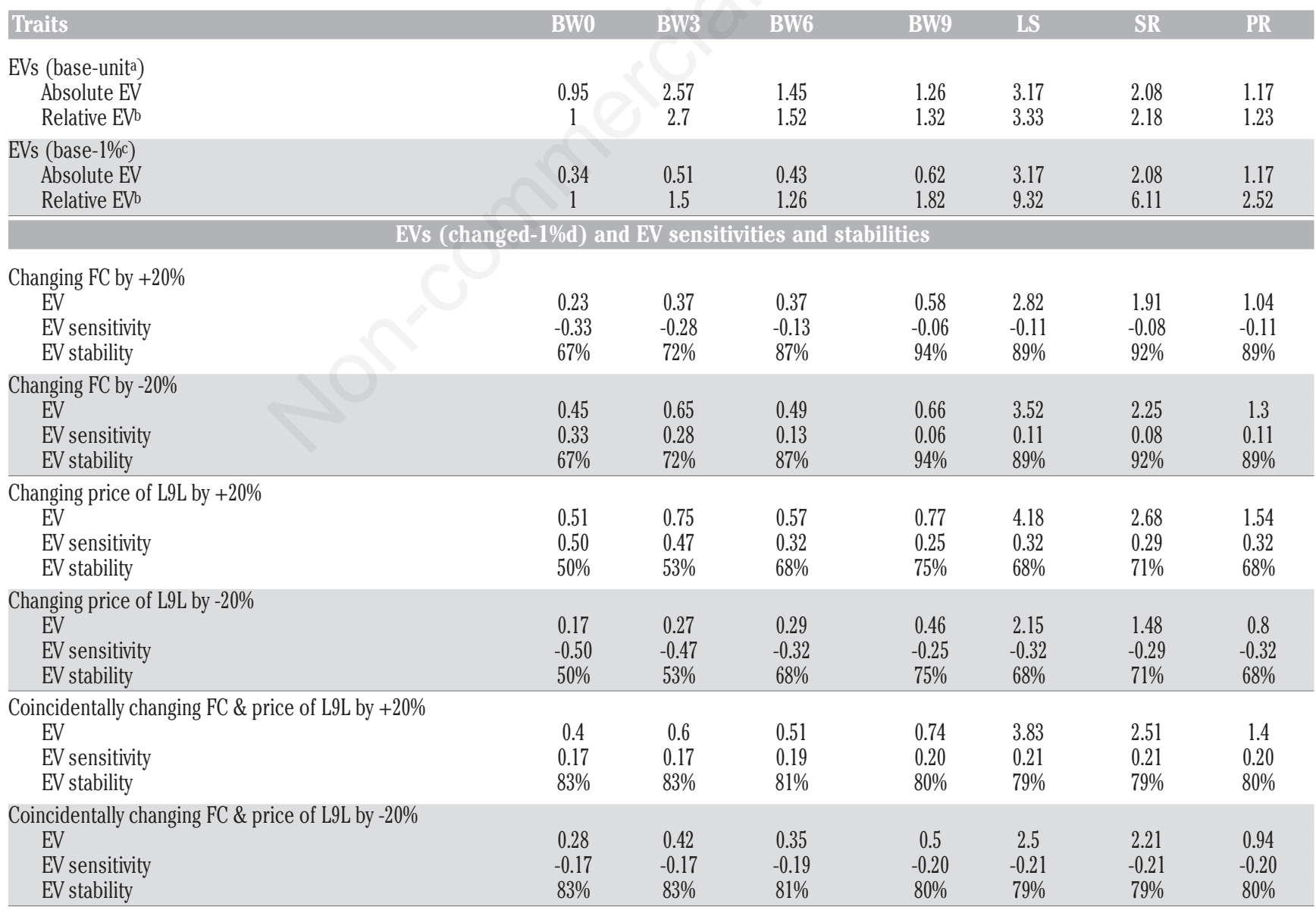

BW0: lamb birth weight; BW3: lamb weaning weight (3 months old); BW6: 6-month-old lamb weight; BW9: 9-month-old lamb weight; LS: litter size; SR: Survival rate before six month; PR: pregnancy rate. aThe EVs calculated by increasing trait mean values by one unit in the base situation. bThe relative EVs of traits was calculated based on the EV of BW0. cThe EVs calculated by increasing trait mean values by $1 \%$ in the base situation. dThe EVs calculated by increasing trait mean values by $1 \%$ in the changed situation. 
uncertainties in sheep production. Body weight in the time of sale was important for the system evaluated in this study. As the only incomes here are the sales of animals, wool and manure, an increase in values of these traits promotes positive increments in the system profit. In the present evaluation, BW9 and BW6 have rank four and five EVs when increased by $1 \%$ increase, respectively. McManus et al. ${ }^{29}$ reported that in the intensive sheep production, the EV of lamb slaughter weight was highest when compared with the values in the extensive and semi intensive production system.

Weaning weight and birth weight have sixth and seventh EVs among considered trait EVs. Khodaei has reported the EV of birth weight of Gillani sheep was negative, because of increasing percentage of mortality rate of ewes and lambs at the lambing time in Gillani breed. ${ }^{26}$ However, in the present study, positive EV of birth weight was probably due to the fact that there were no increased mortality rate and additional costs associated with the heavier lambs born, such as more nutrient requirements or assistance for heavier lambs during the lambing time, as Tolone et al.16 explained these points about birth weight trait.

About the sensitivity of the trait EVs could discussed that these results demonstrated that the sensitivity of BW9, SR, LS and PR EVs to the system input changes is low, therefore because of their high stabilities, they can used as the long-term components of selection index equation for the intensive production system of Zel sheep. With increasing and decreasing the price of live weight of 9 -month-old lamb by $\pm 20 \%$, the EVs of all seven traits increased and decreased, respectively. The EV of BW9 was more sensitive to the revenue changes (the variation of \pm 0.25 ) in comparison to input changes (the variation of \pm 0.06 ). With coincidentally changing feed costs (system input) and price of live weight of 9-monthold lamb (system revenue) by $\pm 20 \%$, all seven trait EVs changed by $\pm 17-21 \%$. With changing system input and income by $\pm 20 \%$, the relative EVs of traits remained constant and ranking of the trait EVs was not changed.

\section{Conclusions}

Intensive sheep production system is a profitable system for Zel sheep and this study provides some important information on the traits that should be included in breeding objectives in the intensive sheep production system for this breed, where annual expenses are very high and manual feeding is the main source of feed for the flock. In Iran, Mazandaran province is the most economical case for sheep production in a closed system because of its special climatic conditions and also Zel breed characters which is native (high resistance and low maintenance cost of mother for its small size). From the results obtained in this study can be concluded that intensive sheep production system is a profitable system for Zel, and the breeding objective that affect profitability in Zel under intensive rearing system in Iran, will be including litter size, survival rate up to 6 months of age, pregnancy rate, and lamb body weight at 9, 3 and 6 months of age, respectively.

\section{References}

1. FAO. Selected indicators of food and agricultural development in the AsiaPacific region 2000-2010. Food and Agriculture Organization of the United Nations, Regional Office for Asia and the Pacific, Bangkok, pp 150. 2011. Available from: http://www.fao.org/ docrep/014/i2371e/i2371e00.pdf

2. Kamalzadeh A. Modeling the productivity of a breeding sheep flock for different production systems. Asian-Aust. J Anim Sci 2005;18:606-12.

3. Petrović PM. Sustainable sheep breeding (Monography). Belgrade: Institute for Animal Husbandry; 2007.

4. Osamu S, Kazuo I, Yoshitaka N. Breeds and breeding systems of dairy sheep in the Mediterranean countries. Exp Herbivora 2005;29:39-48.

5. Hanford KJ, Van Vleck LD, Snowder GD. Estimates of genetic parameters and genetic change for reproduction, weight, and wool characteristics of Columbia sheep. J Anim Sci 2002;80: 3086-98.

6. Hanford KJ, Van Vleck LD, Snowder, GD. Estimates of genetic parameters and genetic change for reproduction, weight, and wool characteristics of Targhee sheep. J Anim Sci 2003;81: 630-40.

7. Hanford KJ, Van Vleck LD, Snowder GD. Estimates of genetic parameters and genetic change for reproduction, weight, and wool characteristics of Rambouillet sheep. Small Rum Res 2005;57:175-86.

8. Notter DR. Genetic evaluation systems and the U.S. sheep industry. Shepherd 2001;46:18-9.

9. Petrović PM, Skalicki Z, Ružić D, Žujović M. Investigation of genetic and paragenetic parameters of milk yield of sheep on Stara Planina mountain. Biotechnol Anim Husbandry 2003;19: 113-7.

10. Snowder GD, Fogarty NM. Composite trait selection to improve reproduction and ewe productivity: a review. Anim Prod Sci 2009;49:9-16.

11. Hazel LN. The genetic basis for constructing selection indexes. Genetics 1943;28:476-90.

12. Conington J, Bishop SC, Waterhouse, A, Simm, G. A bioeconomic approach to derive economic values for pasturebased sheep genetic improvement programs. J Anim Sci 2004;82:1290-304.

13. Kosgey IS, Van Arendonk JAM, Baker RL. Economic values for traits of meat sheep in medium to high production potential areas of the tropics. Small Rum Res 2004;50:187-202.

14. Kosgey IS, Van Arendonk JAM, Baker RL. Economic values for traits in breeding objectives for sheep in the tropics: impact of tangible and intangible benefits. Livest Prod Sci 2004;88:143-60.

15. Lôbo RNB, Pereira IDC, Facó O, McManus CM. Economic values for production traits of Morada Nova Meat sheep in a pasture-based production system in semi-arid Brazil. Small Rum Res 2005;96:93-100.

16. Tolone M, Riggio V, Maizon DO, Portolano B. Economic values for production and functional traits in Valle del Belice dairy sheep using profit functions. Small Rum Res 2011;97:41-7.

17. Vatankhah M. Defining a proper breeding scheme for Lori-Bakhtiari sheep in village system. Ph.D. thesis, Tehran University, Iran (in Persian). 2005.

18. Wang CT, Dickerson GE. A deterministic computer simulation model of lifecycle lamb and wool production. J Anim Sci 1991;69:4312-23.

19. Wolfova M, Wolf J, Milerski M. Economic weights of production and functional traits for Merinolandschaf, Romney, Romanov and Sumavska sheep in the Czech Republic. Small Rum Res 2011;99:25-33.

20. Haghdoost A, Shadparvar A, Beigi Nasiri, MT, Fayazi J. Estimates of economic values for traits of Arabic sheep in village system. Small Rum Res 2008;80:91-4.

21. NRC. Nutrient Requirements of Small Ruminants. Washington, DC: National Academic Press; 2007.

22. Ponzoni RW. A profit equation for the definition of the breeding objective of Australian merino sheep. J Anim Breed Genet 1986;103:342-57.

23. Erkan O, Yılmaz İ, Şengül H. Toros dağ köylerindeki küçük ölçekli tarım işlet- 
melerinin üretim sistemlerinin analizi. Çukurova Üniversitesi Ziraat Fakültesi Dergisi 1993;8:105-20.

24. Yıldırım İ. Van İli Çatak İlçesinde Koyunculuk İşletmelerinin Üretim Ekonomisi ve Pazarlaması. Ph.D. thesis, Ege University, Turkey. 1993.

25. Şahin A, Yildirim I. Economic analysis of sheep farms in center district of Van province. J Agric Sci 2002;12: 47-52.

26. Khodaei M. Defining a proper breeding scheme for Gilani sheep. Ms.c thesis, University of Gilan, Ira. (in Persian). 2006.

27. Legarra A, Ramon M, Ugarte E, PerezGuzman MD. Economic weights of fertility, prolificacy, milk yield and longevity in dairy sheep. Animal 2007;1:193-203.

28. Morais OR, Madalena FE. Economic value for reproduction traits in Santa Inês sheep. In: Proceedings of the 8th
World Congress on Genetics Applied to Livestock Production., Belo Horizonte, Minas Gerais, Brazil, 13-18 August 2006, CD abst. 4_966_1442. 2006.

29. McManus C, Pinto B, Louvandini H, et al. Selection objectives for hair sheep in Central Brazil. In: Proceedings of the 8th World Congress on Genetics Applied to Livestock Production., Belo Horizonte, Minas Gerais, Brazil, 13-18 August 2006, pp. 04-31.2006. 